\title{
Hodgkin's disease: a flow cytometric study
}

\author{
KATE G MORGAN, * P QUIRKE,* C J O'BRIEN,* C C BIRD \\ From the *Department of Pathology, University of Leeds, and the Department of Pathology, University Medical \\ School, Edinburgh
}

SUMMARY Flow cytometry was performed on paraffin embedded tissue from 115 cases of Hodgkin's disease. Thirteen (11\%) tumours were aneuploid with no significant difference between the histological subgroups. The median proliferative index was $14 \%$, and the highest values were found in the NS2 (16.4\%) and lymphocyte depleted (16.0\%) subgroups. The difference in proliferative index approached significance when the NS2 subgroup was compared with the NS1 subgroup $(p \leqslant 0 \cdot 11)$ and when the lymphocyte depleted and NS2 subgroups combined were compared with the mixed cellularity, lymphocyte predominance, and NS1 subgroups combined ( $p \leqslant 0 \cdot 07)$.

There was a trend towards better survival for patients with aneuploid tumours and those cases with a proliferative index below $15 \%$, but neither of these trends was significant.

It is now generally accepted that the Reed-Sternberg cell and its mononuclear variant represent the malignant cells of Hodgkin's disease. Proliferative activity in these cells has been shown by the presence of mitotic figures and the uptake of radiolabelled thymidine. ${ }^{1}$ Cytogenetic studies have also shown aneuploid cells in Hodgkin's disease tissue and a clonal distribution of marker chromosomes, regarded as fundamental characteristics of neoplasms. ${ }^{\prime}$ More recently, cultured cell lines from Reed-Sternberg and mononuclear Hodgkin's disease cells have been established with neoplastic karyotypes. ${ }^{2-5}$ Cells were hyperdiploid, had chromosome numbers ranging from $47-77^{4}$ to $86-$ $90,{ }^{5}$ marker chromosomes, and multiple structural chromosomal abnormalities.

A clear inverse relation exists between the number of Reed-Sternberg and mononuclear Hodgkin's disease cells and the reactive cell population, particularly lymphocytes, in Hodgkin's disease tissue, and this has an important bearing on the clinical outcome of the disease.$^{67}$ Prognosis is also strongly affected by the clinical stage at presentation and histological subtype of disease as defined by the Rye classification. ${ }^{8}$ In 1971 Lukes drew attention to the separate but parallel nature of nodular sclerosing Hodgkin's disease. ${ }^{9}$ in which there can be a spectrum of appearances ranging from lymphocyte predominance through mixed cellularity to lymphocyte depletion. Cross, in a series of 29 patients with nodular sclerosing Hodgkin's

Accepted for publication 16 December 1987 disease,${ }^{10}$ showed reduced survival in those cases where the nodules had lymphocyte depleted pattern. Several subsequent studies have shown a trend towards better survival for cases with lymphocyte predominant nodules ${ }^{11-13}$ and the large series analysed by the British National Lymphoma Investigation (BNLI) confirmed the significantly poorer survival of cases with lymphocyte depleted nodules. ${ }^{14-16}$

Several studies of non-Hodgkin's lymphoma have used flow cytometry to assess the DNA content of tumours. These have shown a higher incidence of DNA aneuploidy and increased numbers of cells in Sphase in high grade compared with low grade tumour. ${ }^{17} 1^{18}$ The presence of DNA aneuploidy did not seem to have prognostic importance, ${ }^{19} 20$ although aneuploid tumours showed a higher remission rate in response to treatment than diploid tumours. ${ }^{21} \mathrm{High}$ numbers of cells in S-phase in non-Hodgkin's lymphoma have also been correlated with decreased survival in some studies, ${ }^{19} 2022$ although this was not confirmed in another study in which patients were followed up for 20 years. ${ }^{21}$ It has also been reported that high values of S-phase cells identify patients with low grade non-Hodgkin's lymphoma who are at risk of transforming to high grade malignancy. ${ }^{23}$

As comparable studies in Hodgkin's disease might yield valuable information, we applied flow cytometry to a large series of Hodgkin's disease cases to assess the significance of differences in ploidy and proliferative index in different histological subgroups, especially in relation to survival. 


\section{Material and methods}

Paraffin embedded tissues from 115 patients with Hodgkin's disease, diagnosed between 1977-86, were obtained from the pathology departments at the General Infirmary and St James's University Hospital, Leeds, York District General Hospital, and Hull Royal Infirmary. Haematoxylin and eosin stained sections were prepared for confirmation of diagnosis and histological classification into one of the following groups: lymphocyte predominance; mixed cellularity; lymphocyte depletion; and nodular sclerosis, using the criteria described by Lukes. ${ }^{9}$ The cases of nodular sclerosis were further subdivided into nodular sclerosis grades 1 (NS1) and 2 (NS2) using the BNLI criteria. ${ }^{15}$

Flow cytometry was performed using a modification ${ }^{24}$ of the method of Hedley et al ${ }^{25}$ Sections $(50 \mu \mathrm{m})$ were cut from paraffin embedded blocks and transferred to glass slides. The sections were dewaxed in xylene and rehydrated by passing through a series of alcohols $(100 \%, 95 \%, 90 \%, 70 \%$ and $50 \%)$. The sections were washed twice in distilled water, the tissue removed with a scalpel and placed in a test tube with a $0.5 \%$ pepsin (Sigma Chemical Company, Poole, BH17 $7 \mathrm{NH}$ ) in $0.9 \%$ sodium chloride, adjusted to $\mathrm{pH} 1.5$ with $2 \mathrm{~N}$ hydrochloric acid, and incubated at $37^{\circ} \mathrm{C}$ for 30 minutes in a waterbath. The cells were centrifuged at $2000 \mathrm{rpm}$, washed twice in distilled water, and stained by suspending in a solution of $1 \mu \mathrm{g} / \mathrm{ml} 4^{\prime} 6^{\prime}$ diamidino-2-phenylindole dihydrochloride (Boehringer Mannheim, West Germany) in RPMI 1640 culture medium at $20^{\circ} \mathrm{C}$ for 30 minutes before filtering through four layers of butter muslin and syringing through a 23 gauge needle. Samples were analysed on an EPICS V flow cytometer (Coulter Electronics, Hialeh, Florida, USA) and for excitation a Coherent Innova $-905 \mathrm{~W}$ UV enhanced argon ion laser was used at $50 \mathrm{~mW}$ power at a wavelength of $350 \mathrm{~nm}$. A 408 $\mathrm{nm}$ interference filter removed scattered incident ultraviolet light. Ten thousand nuclei were counted.

The mean half peak coefficient of variation was $6.46 \%$ (range 3.06-9.97). Aneuploidy was defined as the presence of more than one $G_{0} / G_{1}$ peak ${ }^{26}$ (fig 1 ). The degree of DNA aneuploidy was expressed as the DNA index, which was calculated by dividing the modal channel number of the $G_{0} / G_{1}$ DNA aneuploid peak by the modal channel number of the diploid $G_{0} / G_{1}$ peak.

Cell cycle analysis was performed using PARA 1 (Coulter Electronics, Hialeh, Florida, USA). The $\mathrm{S}+\mathrm{G}_{2}$ fractions of the diploid tumours were combined to give the proliferative index. The $S$ and $G_{2}$ fractions of the DNA aneuploid tumours were not calculated due to the overlap of cell populations. For each case the highest $\mathrm{S}+\mathrm{G}_{2}$ fraction obtained was taken as the proliferative index.

The median age, the male:female ratio, and the

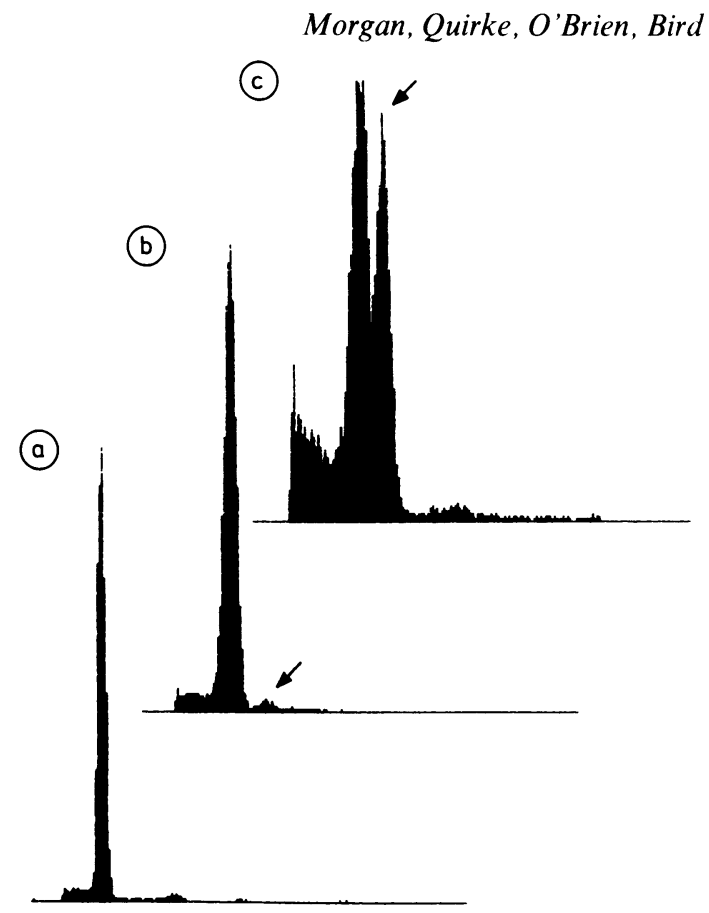

Fig 1 DNA histogram showing: (a) diploid tumour; (b) aneuploid tumour with small abnormal DNA stemline (arrow); (c) aneuploid tumour with large abnormal DNA stemline (arrow).

number of DNA aneuploid tumours were calculated for the whole group and for each histological subgroup. Differences in age (numbers above and below 40 years), male:female ratio, and numbers of DNA aneuploid tumours in the different histological groups were tested by the $\chi^{2}$ test and Fisher's exact test. Differences in the proliferative index between the histological subgroups were tested using the Mann-Whitney U test.

Survival data on 108 patients were obtained through the Yorkshire Regional Cancer Registry. Survival time was calculated to the date of death, or April 1987. The cause of death was not available. Life table analysis was carried out using BMDPIL software and cumulative survival curves in relation to DNA content and proliferative index (above and below $15 \%$ ) were obtained and tested by the log rank test. The NS2 and lymphocyte depleted cases were combined in view of the very low number of lymphocyte depleted cases in the group.

\section{Results}

The table shows the values for age, male:female ratio, number of DNA aneuploid tumours and proliferative index for each histological subgroup. 
Table Results

\begin{tabular}{|c|c|c|c|c|c|}
\hline & $\begin{array}{l}\text { Median } S+G_{2} \\
\left.\text { (range } S+G_{2}\right)\end{array}$ & $\begin{array}{l}\text { No DNA aneuploid } \\
\text { tumours }(\%)\end{array}$ & $\begin{array}{l}\text { Median age } \\
\text { (range })(y r)\end{array}$ & $M: F$ ratio & $\begin{array}{l}\text { No of cases } \\
\%\end{array}$ \\
\hline $\begin{array}{l}\text { Whole group } \\
\text { Lymphocyte } \\
\text { predominance }\end{array}$ & $\begin{array}{l}14 \cdot 0(4 \cdot 3-35 \cdot 0) \\
12 \cdot 7(6 \cdot 2-28 \cdot 1)\end{array}$ & $\begin{array}{c}13(11 \cdot 3) \\
1(5 \cdot 6)\end{array}$ & $\begin{array}{l}37(1-91) \\
40(20-83)\end{array}$ & $\begin{array}{l}1 \cdot 7: 1 \\
17: 1\end{array}$ & $\begin{array}{l}115(100) \\
18(15 \cdot 7)\end{array}$ \\
\hline $\begin{array}{l}\text { Mixed cellularity } \\
\text { Lymphocyte } \\
\text { depletion }\end{array}$ & $\begin{array}{l}13 \cdot 5(7 \cdot 0-21 \cdot 4) \\
16 \cdot 0(4 \cdot 3-27 \cdot 5)\end{array}$ & $\begin{array}{l}5(22 \cdot 7) \\
0(0)\end{array}$ & $\begin{array}{l}41(1-72) \\
25(23-45)\end{array}$ & $\begin{array}{l}1: 1 \\
3: 0\end{array}$ & $\begin{array}{c}22(19 \cdot 1) \\
3(2 \cdot 6)\end{array}$ \\
\hline $\begin{array}{l}\text { NS1 } \\
\text { NS2 }\end{array}$ & $\begin{array}{l}14 \cdot 0(5 \cdot 0-27 \cdot 3) \\
16 \cdot 4(7 \cdot 8-35 \cdot 0)\end{array}$ & $\begin{array}{l}5(9 \cdot 4) \\
2(10 \cdot 5)\end{array}$ & $\begin{array}{l}33(5-91) \\
39(11-80)\end{array}$ & $\begin{array}{l}1 \cdot 8: 1 \\
0 \cdot 6: 1\end{array}$ & $\begin{array}{l}53(46 \cdot 1) \\
19(16 \cdot 5)\end{array}$ \\
\hline
\end{tabular}

\section{FLOW CYTOMETRY}

The highest proportions of DNA aneuploid tumours were seen in the mixed cellularity $(22 \cdot 7 \%)$ and NS2 $(10.5 \%)$ subgroups, but significant differences in numbers of DNA aneuploid tumours between the histological subgroups were not observed. The DNA index of the DNA aneuploid tumours varied between 1.2-1.82 (median 1.55).

The highest proliferative indices were found in the NS2 (median 16.4\%) and lymphocyte depleted (median $16.0 \%$ ) subgroups. The differences in proliferative index approached significance when the NS2 subgroup was compared with the NS1 subgroup $(\mathrm{p} \leqslant 0 \cdot 11)$ and when the lymphocyte depleted and NS2 subgroups were combined and compared with the combined mixed cellularity, lymphocyte predominance, and NS1 subgroups ( $\mathrm{p} \leqslant 0.07)$.

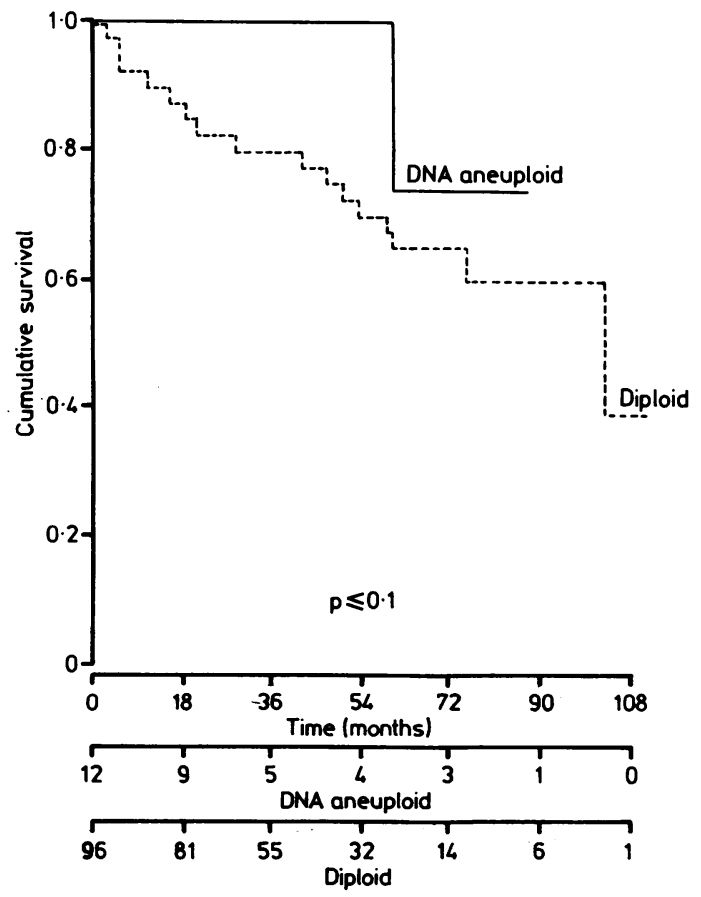

Fig 2. Cumulative survival curve in relation to DNA content.

\section{SUR VIVAL STUDIES}

The median follow up of patients was 39 months (range 2 to 110 months). At the time survival data were calculated, 79 patients were alive and 29 had died.

Of the 108 patients for whom survival data were available, ninety six patients had diploid tumours and 12 had DNA aneuploid tumours. The survival of patients with DNA aneuploid tumours was improved when compared with those with diploid tumours and this approached significance $(p \leqslant 0 \cdot 1)$ (fig 2$)$. Of the 96 patients with diploid tumours, 56 had a proliferative index of less than $15 \%$ and 40 had a proliferative index equal to or greater than $15 \%$. There was a trend towards better survival for cases with a proliferative index below $15 \%$, compared with higher proliferative indices, but this did not reach significance $(p \leqslant 0.5)$ (fig 3).

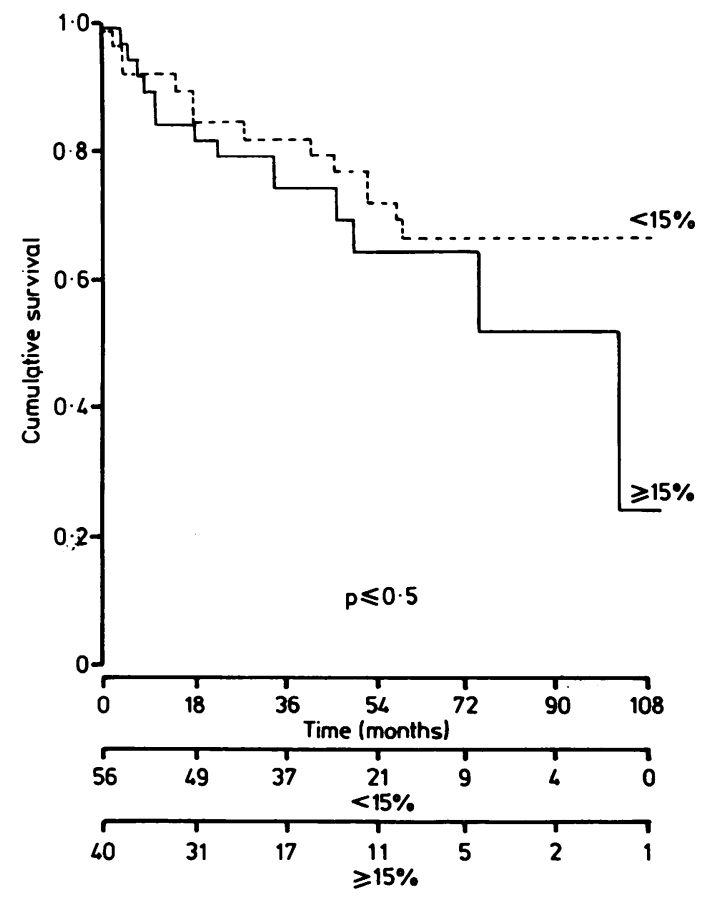

Fig 3 Cumulative survival curve in relation to proliferative index $\left(\% S+G_{2}\right)$. 


\section{Discussion}

The only previous flow cytometry study of Hodgkin's disease is that of Diamond et al, ${ }^{17}$ who analysed eight cases, one of which showed a small DNA aneuploid population of cells in the near tetraploid range. Morphological studies showed this to be a case of nodular sclerosis with relative lymphocyte depletion and large numbers of abnormal mononuclear cells. It was assumed that aneuploid cell population corresponded to the Reed-Sternberg and mononuclear Hodgkin's cells. In our study we found DNA indices in the hyperdiploid to near tetraploid range, consistent with previously estimated chromosome numbers in Reed-Sternberg cells. ${ }^{145}$ Compared with studies of non-Hodgkin's lymphoma, the overall percentage of DNA aneuploid tumours is low, ${ }^{17-21}$ possibly because the DNA aneuploid cell population in Hodgkin's disease is diluted by the presence of a large reactive non-neoplastic diploid cell population. It might be expected that the rate of aneuploidy would vary with the histological subtype of Hodgkin's disease. Although we found a higher incidence of aneuploidy in the groups with less favourable histological results, there was not the clear cut association seen with high grade non-Hodgkin's lymphoma. The trend observed towards better survival of patients with Hodgkin's disease with DNA aneuploid tumours may relate to the association of aneuploidy in high grade nonHodgkin's lymphoma, with more likely attainment of complete remission following treatment. ${ }^{21}$ This association has also been reported in childhood acute lymphocytic leukaemia.?

It must be assumed that the proliferative index of Hodgkin's disease tissue reflects the rate of proliferation of both the reactive and neoplastic (ReedSternberg and mononuclear Hodgkin's disease) cells. Although the median proliferative index was highest in the subgroups with least favourable histology, this was not significant, in contrast to the findings in high grade non-Hodgkin's lymphoma. There was a trend towards better survival, however, in the subgroups with a proliferative index below $15 \%$, as was found in low grade non-Hodgkin's lymphoma. ${ }^{21}$

From the results of this study, we conclude that flow cytometry is unlikely to yield much useful information in determining the prognosis of different histological subtypes of Hodgkin's disease, and that clinical and morphological factors still remain the mainstay of assessment and prognostic indication. Dual parameter flow cytometry of fresh Hodgkin's disease tissue labelled with putative markers of Reed-Sternberg and mononuclear Hodgkin's disease cells (such as the $\mathrm{K}_{1}-1$ monoclonal antibody) and counterstained for DNA content, however, will permit more sensitive assessment of the presence of aneuploidy and the degree of cell proliferation in these tumours.
We thank the consultant pathologists at St James's University Hospital, Leeds, York District General Hospital, and Hull Royal Infirmary for their generosity in providing cases for this study. Technical assistance was provided by Mrs C L North, Mr N Dudding, and Mr R Stretton. Mrs Jacquie Fearnley provided secretarial assistance. The work was supported by grants from the Yorkshire Cancer Research Campaign, Harrogate, Yorkshire.

\section{References}

1 Kaplan HS. Pathology. In: Hodgkin's disease. 2nd ed. Cambridge, Massachusetts: Harvard University Press, 1980:52-115.

2 Diehl V, Burrichter H. Schaadt M, et al. Hodgkin's cell lines: characteristics and possible pathogenetic implications. Hematol Oncol 1983;1:139-47.

3 Poppema S, De Jand B, Atmosoerodjo J, Venburg V, Visser I, De Ley L. Morphologic, immunologic, enzyme histochemical and chromosomal analysis of a cell line derived from Hodgkin's disease. Evidence for a B cell origin of Sternberg Reed cells. Cancer 1985;55:683-90.

4 Olsson L, Behnke O, Pleibel N, et al. Establishment and characterization of a cloned giant cell line from a patient with Hodgkin's disease. JNCI 1984;73:809-30.

5 Jones DB, Scott CS, Wright DH, et al. Phenotypic analysis of an established cell line derived from a patient with Hodgkin's disease. Hematol Oncol 1985;3:133-45.

6 Lukes RJ, Butler JJ. The pathology and nomenclature of Hodgkin's disease. Cancer Res 1966;26:1063-81.

7 Coppleson LW, Rappaport H, Strum SB, Rose J. Analysis of the Rye classification of Hodgkin's disease. The prognostic significance of cellular composition. JNCI 1973;51:379-90.

8 Lukes RJ, Craven LF, Hall TC, Rappaport H, Ruben P. Report of the Nomenclature Committee. Cancer Res 1966;26(part 1): 1131.

9 Lukes RJ. Criteria for involvement of lymph node, bone marrow, spleen and liver in Hodgkin's disease. Cancer Res 1971;31: $1755-67$.

10 Cross RM. A clinicopathological study of nodular sclerosing Hodgkin's disease. J Clin Pathol 1968;21:303-10.

11 Keller AR, Kaplan HS, Lukes RJ, Rappaport H. Correlation of histopathology with other prognostic indicators in Hodgkin's disease. Cancer 1968;22:487-99.

12 Patchesfsky AS, Brodovsky H, Southard M, Menduke H, Gray S. Hoch WS. Hodgkin's disease. A clinical and pathologic study of 235 cases. Cancer 1973;32:150-61.

13 Cionini L, Arganini L, Mungai V, Biti GP, Bondi R. Prognostic significance of histologic subdivision of Hodgkin's disease nodular sclerosis. Acta Radiol Oncol 1978;17:65-73.

14 Bennett MH, Tu A, Vaughan Hudson G. Analysis of grade I Hodgkin's disease. (BNLI Report No 6) Clin Radiol 1981;32:491-8.

15 Bennett MH, Maclennan KA, Easterling MJ, Vaughan Hudson B, Jelliffe AM, Vaughan Hudson G. The prognostic significance of cellular subtypes in nodular sclerosing Hodgkin's disease: an analysis of 271 non-laparotomised cases. (BNLI Report No 22) Clin Radiol 1983;34:497-501.

16 Maclenan KA, Bennett MH, Tu A, et al. The prognostic significance of cytological subdivision of nodular sclerosing Hodgkin's disease: analysis of 1156 patients. In: Cavalli F, ed. Proceedings of the Second International Symposium of malignant lymphomas. Boston Spa 1984.

17 Daimond LW, Nathwani BN, Rappaport H. Flow cytometry in the diagnosis and classification of malignant lymphoma and leukaemia. Cancer 1982;50:1122-35.

18 Shackney SE, Levine AM, Fisher RI, et al. The biology of tumour growth in the non-Hodgkin's lymphoma. A dual parameter flow cytometry study of 220 cases. J Clin Invest 1984;73:1201-14.

19 Roos G, Dige U, Lenner P, Lindh J, Johansson H. Prognostic 
significance of DNA analysis by flow cytometry in nonHodgkin's lymphoma. Hematol Oncol 1985;3:233-42.

20 Bauer KD, Merkel DE, Winter JN, et al. Prognostic implications of ploidy and proliferative activity in diffuse large cell lymphomas. Cancer Res 1986;46:3173-8.

21 Morgan DR, Williamson JMS, Quirke P, et al. DNA content and prognosis of non-Hodgkin's lymphoma. Br J Cancer 1986;54: $1-7$.

22 Braylan RC, Diamond LW, Powell ML, Harty-Golder B. Percentage of cells in the S-phase of the cell cycle in human lymphoma determined by flow cytometry. Correlation with labelling index and patient survival. Cytometry 1980;1:171-4.

23 McCartney JC, Camplejohn RS, Alder J, Stone MG, Powell G. Prognostic importance of DNA flow cytometry in nonHodgkin's lymphoma. J Clin Pathol 1986;39:542-6.

24 Quirke P, Fozard JBJ, Dixon MF, Dyson JED, Giles GR, Bird
CC. DNA aneuploidy in colorectal adenomas. Br J Cancer 1986;53:477-81.

25 Hedley DW, Friedlander ML, Taylor IW, Rugg CA, Musgrove EA. Method for analysis of cellular DNA content of paraffinembedded pathological material using flow cytometry. $J$ Histochem Cytochem 1983;31:1333-5.

26 Hiddeman W, Schumann J, Andreeff M, et al. Convention on nomenclature for DNA cytometry. Cancer Genet Cytogenet 1984;13:181-3.

27 Smets LA, Homan-Blok J, Hart A, et al. Prognostic implication of hyperdiploidy as based on DNA flow cytometric measurement in childhood acute lymphocytic leukaemia-A multicentre study. Leukaemia 1987;1:163-6.

Requests for reprints to: Dr K G Morgan, Department of Pathology, University of Leeds, Leeds LS2 9JT, England. 